\title{
Perceived Academic Stress Among Students in Universiti Teknologi Malaysia
}

\author{
Marlissa Omar ${ }^{*}$, Aina Hazimah Bahaman², Faridah Aminullah Lubis ${ }^{3}$, \\ Shahrel Ahmad Shuhel Ahmad ${ }^{4}$, Fahmi Ibrahim ${ }^{5}$, Siti Norbiha A. Aziz ${ }^{6}$, Fairuz Diyana Ismail ${ }^{7}$, \\ Abd Rahman Bin Tamuri ${ }^{8}$ \\ ${ }^{1}$ Department of Technical and Engineering Education, School of Education, Faculty of Social Sciences and \\ Humanities, Universiti Teknologi Malaysia \\ ${ }^{2}$ Department of Chemistry, Faculty of Science, Universiti Teknologi Malaysia \\ ${ }^{3}$ Department of Biosciences, Faculty of Science, Universiti Teknologi Malaysia \\ ${ }^{4}$ Centre of Research for Fiqh Science \& Technology (CFiRST), Universiti Teknologi Malaysia \\ ${ }^{5}$ Department of Physics, Faculty of Science, Universiti Teknologi Malaysia \\ ${ }^{6}$ Production Laboratory, School of Mechanical, Faculty of Engineering, Universiti Teknologi Malaysia \\ ${ }^{7}$ Department of Physics, Faculty of Science, Universiti Teknologi Malaysia \\ ${ }^{8}$ Department of Physics, Faculty of Science, Universiti Teknologi Malaysia \\ *Corresponding Author Email: marlissa.utm@gmail.com
}

\begin{abstract}
Students are the next generation of leaders to govern the country. However, many pressures affect their performance and life at university such as academic and social pressures. These pressures can sometimes cause stress among students. Having suicidal thoughts, drugs addiction, and dropping out of college are some of the situations that might be caused by pressures and stress among students. Among all types of stress faced by students, academic stress is one of the reasons why some students fall into deeper problems such as depression and anxiety. Academic stress can come from various reasons such as lecturers, assignments, peers and much more. Thus, this paper aims to identify the academic stress level among students in Universiti Teknologi Malaysia (UTM). 100 students has been involved in this study which require them to answer a survey regarding sources of stress. The result from the survey is analyzed to determine the level of stress according to each source of stress. This study found that students mostly suffer from high academic stress due to results, tests, peers and self-inflicted stress. The results from this study will enable students, educators and universities to observe and take action on how to help students who suffer from academic stress during their study and for future research to further explore in this issue. Keywords: Academic stress, University students, Stress, Pressure
\end{abstract}

\section{INTRODUCTION}

According to the World Health Organization (WHO), mental disorders are one of the factors that contribute to disability among people between the ages of 14 to 44 . Various reasons can be one of the causes of mental disorders. Stress is one of the conditions that can threaten our state of mind and well-being [1]. Stress itself is a complex and complicated subject [2]. According to Neil [3], "stress has been around and has been noticed for ages". It can affect everyone regardless of their age, gender, educational status or socioeconomic status. For some people, stress may refer to an uncomfortable emotion, while for some, it is a situation that affects someone's manner of thinking. Stress can be defined as "any situation that evokes negative thoughts and feelings in a person. The same situation is not evocative or stressful for all people, and all people do not experience the same negative thoughts and feelings when stressed" [4]. Thus, it can be concluded that stress can happen when a specific situation triggers someone's emotions and negative thinking. However, this does not apply to everyone since everyone has their own types of pressures that can be the reason for the stress itself.

Students are the next generation of leaders to govern the country. However, many pressures affect their performance and life at university. These pressures can sometimes cause stress among students. Undergraduate university students are a group of people that are going through a transition period between adolescent and adulthood [5]. This transition period is identified as one of the most stressful periods in a person's life according to various research. Thus, it 
is most likely for this group of people to be affected with academic stress due to continuous pressure that they received while transitioning into the adulthood period.

Based on a study by Yikealo, Tareke and Karvinen [6], academic and environmental stressors contribute the most towards students' level of stress out of five main domains (physiological, social, environmental psychological and academic,). According to Shaikh et al. [7], students are subjected to all kind of academic pressures where they continuously think they need to do well in their study and feels uncertain about their future. The mindset of the students especially in Malaysia also contributes to the ongoing pressures among students where the majority of students feel the need to secure a high Cumulative Grade Point Average (CGPA) in their study to secure a better job for the future. This type of mindset will eventually trigger mental and emotional pressure, tension, or stress that occurs due to the demands of university life, which causes academic stress among university students. It is essential to identify academic stress among students in Malaysian higher education institute to be able to provide the solution to help reduce the probability of more students facing this problem, thus promote healthy academic life among students in higher institutions. Hence, this study aims to investigate the academic stress level among students in Universiti Teknologi Malaysia (UTM). This study will investigate two research questions as follow:

1. What is the level of academic stress among UTM students according to the sources of academic stress?

2. What is the level of academic stress among UTM students according to year of study?

\section{LITERATURE REVIEW}

\subsection{Academic Stress}

The mental health of students has become a significant concern in public health with the predominant factor is due to academic stress. Stress can be defined as the body's reaction to the changes that occur in one's life. The response can be observed in both neurologically and physiologically to adjust to the new condition [8]. Academic stressors have long been associated with negative impacts such as poor academic performance [910], mental health problems [11-12], and dropouts [13]. This is in accordance with the mushrooming of a stress intervention program designed for university students to help them in managing stress [14-15].

Whilst the impact of the stressors differs amongst students, and the level of stress is varied throughout the study period, previous studies have been reported that the first year of student life is the period in which students are most vulnerable [16-18]. The vulnerabilities are due to the fact that during that particular time, students are adjusting to the new environment of university life that is different from school life. Besides, they are also in the phase of finding their new identity to fit in the transition phase. Another study that evaluates the correlation among the period of study and the stressors reported that a high strain level was observed in the first semester, and significantly declined towards the second semester [19]. This finding signifies the fluctuation of the mental health of the students while dealing with different levels of stressors in that particular semester. However, a contradicting result has also been reported that a stable level of stress has been observed throughout the first academic year [20-21], reflecting that the level of stress might be as well dependent on the various academic stressors that can be interpersonal or intrapersonal [22].

Interpersonal can be related to difficulties face when dealing with peers, university staff, faculty-relationship and roommates that are found to arise from the pressure of studying and the emotional exhaustion during the adaptation period of university life. While the intrapersonal is varied and often resulted from the students' perception in coping with the stress. Stressrelated to the lecturers are the prominent stressors due to the expectation of the lecturers toward the university student while neglecting the fact that the first-year students are still in the transition phase and incapable of coping with high expectations and demand [23]. This situation can be worsened with intense competition among students to gain the lecturers' recognition and favouritism. Even though peers and relationship stressors appear to be less prevalent, however, homophily and belongingness may result in a situation where demotivated students are disengaged [24].

\subsection{Effects of Academic Stress}

Based on a study by Ramachandiran and Dhanapal (2018), 88 per cent of the respondents in their research agree that studies are the main contributor towards their increasing academic stress while 78 per cent admitted suffering from moderate stress level. Academic stress can cause many adverse physical and mental side effects if it is not controlled. Academic stress usually is associated with a sense of competition and motivation among students [25]. Typically, academic stress can help promote learning among students. Nevertheless, it can also lead to anxiety, helplessness, which could adversely affect students' life and academic performance [26]. It can also affect social interactions with peers and attitudes towards authorities at large [27]. Various researches have identified adverse effects of academic stress towards students both physically and psychologically. 
Various social issues among students in higher institutions result from stress-related factors. Substance abuse, academic misconduct, thievery, as well as attitude problems, are among the issues identified by researchers in this field [28-29]. A study in South African found that students tend to resort to substance use as a means to cope with academic stress [29]. Nevertheless, some students use alcohol as a way to reduce pressure when learning [30]. Such strategies are used by students as they feel it can reduce stress when studying. Furthermore, most students are also conscious of how these can contribute to another issue that could affect their well-being. Findings of a study conducted in Mexico City, Guadalajara and Monterrey have identified that students tend to show criminally violent behavior and bullying-aggression due to substance and alcohol use [31]. All of these are related to the behaviour and attitude problems that will likely to affect their future.

Academic stress also can affect health condition where people that have a high level of stress often suffers from lack of energy, loss of appetite, headaches, insomnia or gastrointestinal problems [32]. A study by Ramachandiran and Dhanapal [32] found that 54 per cent of their respondents experience sleeping disorders. Apart from that, suffering from a high level of academic stress might also lead to mental health such as anxiety, depression and suicidal thoughts [33]. It is essential to address all these issues due to the alarming numbers of students facing difficulties to cope with their academic life. Parents expectations, competitions between peers, heavy syllabus are among the reasons why students are facing these problems. Thus, there is a need to increase awareness on the issue of academic stress among students in higher institutions in order to reduce the numbers of students suffering from a high level of academic stress. It is essential to reduce the number of students suffering from a high level of academic pressure to create a healthy academic lifestyle and to maintain a promising future for them.

\section{METHODOLOGY}

This study is conducted based on a quantitative method. A quantitative method is used in this study based on the methods used by previous researchers in this field [6;34]. The research instrument used in this study consists of a questionnaire adapted from the academic stress inventory developed by Lin and Chen [35]. In this study, a total of 100 respondents is involved ranging from students in their first, second, third and fourth year. Table 1 shows the number of respondents according to the year of study.
Table 1. Number of Respondents according to Year of Study

\begin{tabular}{|c|c|}
\hline Year of Study & $\begin{array}{c}\text { No. of } \\
\text { Respondents }\end{array}$ \\
\hline 1 & 36 \\
\hline 2 & 39 \\
\hline 3 & 11 \\
\hline 4 & 14 \\
\hline TOTAL & $\mathbf{1 0 0}$ \\
\hline
\end{tabular}

A questionnaire has been used as a research instrument in this study to identify students' academic stress levels. The questionnaire consists of 33 items divided into seven constructs adapted from the academic stress inventory. The constructs included in the questionnaire are stress from lecturers, stress from results, stress from tests, stress from studying in a group, stress from peers, stress due to time management, and self-inflicted stress. The results from the survey are then analyzed using descriptive statistics to identify the average mean score for each construct. The average mean score obtained from the analysis will be interpreted using the mean interpretation level, as shown in Table 2.

Table 2. Mean Interpretation Level

\begin{tabular}{|c|c|}
\hline Average Mean & Interpretation \\
\hline $4.50-5.00$ & Very High \\
\hline $3.50-4.49$ & High \\
\hline $2.50-3.49$ & Average \\
\hline $1.50-2.49$ & Low \\
\hline $1.00-1.49$ & Very Low \\
\hline
\end{tabular}

\section{RESULTS AND FINDINGS}

\subsection{The level of academic stress among UTM students according to the sources of academic stress}

This survey has been conducted to focus on the stress level of University Technology Malaysia's students, including both local and international. This survey is done as a means to provide information to the higher institutions and students on the subject of academic stress. This information is intended to give awareness of what causes academic stress and possible effects that it causes to those who suffer from academic stress. Individual perceptions play an important role in predicting stress-related ill-health. A total of 100 respondents have participated in this online survey. The mean scores obtained from the survey is then classified into five levels of academic stresses from very high (4.50$5.00)$ to very low (1.00-1.49). The first part of this study aims to investigate the level of academic stress among UTM students according to the sources of academic stress. Seven different sources of stress have been chosen. The sources of stress are stress from lecturers, the stress from results, the stress from tests, the stress from studying in a group, the stress from peers, the stress due to time management and the self- inflicted stress. 
Table 3 indicates the mean scores for the items under stress from lecturer's construct. The items included in the construct are the difficulties of exercise, the explanation from the lecturer, too much time spending on data research, the language, teaching method and the speed of lecturer instruction. The highest mean scores for this category is from item $7(\mathrm{M}=3.82, \mathrm{SD}=.881)$ which is 'I feel that once I went to university, I wasn't able to keep up with the speed of instruction by the lecturers.', while the lowest is from item $4(\mathrm{M}=2.35$, $\mathrm{SD}=1.149$ ) with the description of 'I feel that I do not understand a lot about some lecturers' teaching content'. Various studies across the globe have highlighted that students that have excessive stress during the study could lead to psychological problems like depression and anxiety.

Table 3. Mean Scores for Stress from Lecturers Items

\begin{tabular}{|l|l|c|c|}
\hline No. & ITEMS & Mean & Std. Deviation \\
\hline 1. & $\begin{array}{l}\text { I think that the forms and content of workouts and reports } \\
\text { Some of the lecturers are excessively stern. }\end{array}$ & 3.18 & .957 \\
\hline 2. & $\begin{array}{l}\text { I feel that the assignments and reports some lecturers are } \\
\text { too difficult. }\end{array}$ & 3.03 & 1.123 \\
\hline 3. & $\begin{array}{l}\text { I feel that the assignments and reports of some lecturers } \\
\text { are a lot too much. }\end{array}$ & 3.30 & 1.020 \\
\hline 4. & $\begin{array}{l}\text { I feel I don't understand much of the teaching content of } \\
\text { some lecturers. }\end{array}$ & 2.35 & 1.149 \\
\hline 5. & $\begin{array}{l}\text { I feel a lot of strain because some subjects use foreign } \\
\text { language books. }\end{array}$ & 3.42 & 1.112 \\
\hline 6. & $\begin{array}{l}\text { I feel I can't adapt to some lecturers' methods for } \\
\text { instruction. }\end{array}$ & 3.18 & 1.086 \\
\hline 7. & $\begin{array}{l}\text { I feel that once I went to university, I wasn't able to keep } \\
\text { up with the speed of instruction by the lecturers. }\end{array}$ & 3.82 & .881 \\
\hline 8. & $\begin{array}{l}\text { I have to waste a lot of time in some classes searching for } \\
\text { knowledge and results. }\end{array}$ & 2.68 & 1.406 \\
\hline
\end{tabular}

Table 4 indicates the mean scores for under stress from results construct. The item including of their parent expectation, result differentiation from high school and the imperfect result. Item 11 (I feel that there is a vast difference between my current results and high school results) shows a higher mean scores with the score of
$\mathrm{M}=3.93, \mathrm{SD}=1.121$, meanwhile item 9 'I feel that my parents think that I did not take my studies seriously' has the lowest mean scores $(\mathrm{M}=2.81, \mathrm{SD}=1.300)$. It's common for students to feel a certain amount of pressure when the exam week is just around the corner. However, some students feel more pressure due to the expectations of the people around them, including parents.

Table 4. Mean Scores for Stress from Results Items

\begin{tabular}{|l|l|c|c|}
\hline No. & ITEMS & Mean & Std. Deviation \\
\hline 9. & $\begin{array}{l}\text { I feel that my parents think that I did not take my studies } \\
\text { seriously }\end{array}$ & 2.81 & 1.300 \\
\hline 10. & $\begin{array}{l}\text { Due to my academic performance, I have conflicts with } \\
\text { my parents. }\end{array}$ & 3.84 & 1.070 \\
\hline 11. & $\begin{array}{l}\text { I feel that there is a significant difference between my } \\
\text { current results and high school results. }\end{array}$ & 3.93 & 1.121 \\
\hline 12. & $\begin{array}{l}\text { I worry that my academic results will not meet my } \\
\text { parents' expectations. }\end{array}$ & 3.74 & 1.041 \\
\hline 13. & $\begin{array}{l}\text { I assume that the outcomes of my recent academic } \\
\text { evaluations are misinformed and withdrawn. }\end{array}$ & 1.141 \\
\hline
\end{tabular}

Table 5 shows the mean scores for stress from tests. The measuring item, including staying up late, feeling worried about failure and the content of the test is included in the construct. The highest mean score for this construct is items 15 (I sleep late due to studying for exams) with the mean score of $\mathrm{M}=4.12, \mathrm{SD}=.946$. Meanwhile, the lowest mean score is item $17(\mathrm{M}=3.67$,
$\mathrm{SD}=1.155$ ) 'I feel that class syllabus and test outlines are uncertain causes me to be unable to prepare as much as I can.'. Imposing too much pressure on oneself can also cause stress. Students who put too much pressure on themselves always feel worried about the outcome of their test. They tend to worry about the possibility to fail on their test or received low scores than their peers. However, too much worrying and pressure can inevitably cause academic stress. 
Table 5. Mean Scores for Stress from Tests Items

\begin{tabular}{|l|l|c|c|}
\hline No. & ITEMS & Mean & Std. Deviation \\
\hline 14. & $\begin{array}{l}\text { I often do not get good enough sleep at night because I } \\
\text { worry about the tests. }\end{array}$ & 3.97 & .937 \\
\hline 15. & $\begin{array}{l}\text { I sleep late due to studying for exams. } \\
\text { I worry that I have to retake the core subjects in } \\
\text { which I fail. }\end{array}$ & 4.12 & .946 \\
\hline 16. & $\begin{array}{l}\text { I feel that class syllabus and test outlines are } \\
\text { uncertain causes me to be unable to prepare as much } \\
\text { as I can. }\end{array}$ & 3.67 & .928 \\
\hline 17. & 1.155 \\
\hline
\end{tabular}

Table 6 indicates the mean scores for stress from studying group construct. The items for this construct includes facing problem on sharing work, not having good team members and anxiety due to presentation. The highest mean score is item $18(\mathrm{M}=3.74, \mathrm{SD}=1.260)$ ' $\mathrm{I}$ often have problems with how to share work with my classmates when some exercises or reports are required', at the same time the lowest mean score isitem 20 (I worry that my classmates will laugh at my inability to perform well when I give a speech or presentation) with the score of $\mathrm{M}=2.96$ and $\mathrm{SD}=1.317$. Students who seem to be nervous about doing group work could also quickly get frustrated and end up putting stress on themselves to ensure that they can finish their work according to their standards.

Table 6. Mean Scores for Stress from Studying in Group Items

\begin{tabular}{|l|l|c|c|}
\hline No. & ITEMS & Mean & Std. Deviation \\
\hline 18. & $\begin{array}{l}\text { I often have problems with how to share work with my } \\
\text { classmates when some exercises or reports are required. }\end{array}$ & 3.74 & 1.260 \\
\hline 19. & $\begin{array}{l}\text { I worry that I will not be able to find a suitable group } \\
\text { member when group work is required to complete an } \\
\text { exercise or report. }\end{array}$ & 3.31 & 1.212 \\
\hline 20. & $\begin{array}{l}\text { I worry that my classmates will laugh at my inability to } \\
\text { perform well when I give a speech or presentation, }\end{array}$ & 2.96 & 1.317 \\
\hline 21. & $\begin{array}{l}\text { I feel that my feeling is hurt when my peer used vulgar } \\
\text { words. }\end{array}$ & 3.61 & 1.230 \\
\hline 22. & $\begin{array}{l}\text { I feel nervous when I need to make a speech or give a } \\
\text { presentation. }\end{array}$ & 3.32 & 1.197 \\
\hline
\end{tabular}

Table 7 indicates the mean scores for stress from peers construct. The items for this construct is disturbance from the class environment and the inability to achieve a good result compared to others. Based on the findings, item 25 "I feel that there are open strife and veiled struggles among classmates due to academic performance" tops the chart with the mean score of
$\mathrm{M}=3.95, \mathrm{SD}=1.175$. Simultaneously, item 23 has the lowest mean, $\mathrm{M}=3.44, \mathrm{SD}=1.209$, which is "When I want to study on my own, I am often affected by my classmates' chatting". Students need to be conscious of the root cause of their stress and anxiety so that they can have a better understanding of it and seek ways to limit and prevent it.

Table 7. Mean Scores for Stress from Peers Items

\begin{tabular}{|l|l|c|c|}
\hline No. & ITEMS & Mean & Std. Deviation \\
\hline 23. & $\begin{array}{l}\text { I am often impacted by my classmates chatting when I } \\
\text { want to study on my own. }\end{array}$ & 3.44 & 1.209 \\
\hline 24. & $\begin{array}{l}\text { I feel that during lesson and my colleagues are very loud. } \\
\text { This influences situations in my class. }\end{array}$ & 3.66 & .956 \\
\hline
\end{tabular}




\begin{tabular}{|l|l|c|c|}
\hline 25. & $\begin{array}{l}\text { I feel there are open hardships and veiled fights, } \\
\text { due to academic performance amongst classmates. }\end{array}$ & 3.95 & 1.175 \\
\hline 26. & $\begin{array}{l}\text { I am very stress that my academic results are not as } \\
\text { good as those of my classmates are. }\end{array}$ & 3.58 & .997 \\
\hline
\end{tabular}

Table 8 indicates the mean scores for stress due to time management construct. The items related to this construct is on the difficulties of the student to balance their time for social activities and academic work. The topmost mean is item 29, which is I feel that social events and student association affect my academic work $(M=3.63$,
$\mathrm{SD}=1.353$ ). On the contrast, the lowest is item 28 (I feel that it is very difficult for me to find a balance between my academic and social activities) with the value of $\mathrm{M}=3.29$, $\mathrm{SD}=1.122$. It is shown that students who think they spent their time wisely have a greater degree of satisfaction with their job and their lives. Students have showed less stress and pressure if they felt they had better control of their time.

Table 8. Mean Scores for Stress due to Time Management Items

\begin{tabular}{|l|l|c|c|}
\hline No. & ITEMS & Mean & Std. Deviation \\
\hline 27. & $\begin{array}{l}\text { I could not adjust and schedule the time to } \\
\text { efficiently linking academic and social activities. }\end{array}$ & 3.37 & 1.070 \\
\hline 28. & $\begin{array}{l}\text { It is very hard for me to find a balance between my } \\
\text { academic and social activities. }\end{array}$ & 3.29 & 1.122 \\
\hline 29. & $\begin{array}{l}\text { My academic work affected by my social activities and } \\
\text { student association. }\end{array}$ & 3.63 & 1.353 \\
\hline
\end{tabular}

Table 9 indicates the mean scores for the self-inflicted stress construct. The items related to this construct is their confident level on their learning performance, interest in the subjects and difficulties to keep up with the courses. The highest mean score are from items 32 (I feel that I have no interest in some subjects or academics) and item 33 (I feel that after I entered university, my performance was not as good as I had expected) with the mean score of $\mathrm{M}=3.61$. Concurrently, the lowest mean score is from item 30 , which is "I feel that my learning level is not as good as that of my classmates" $(\mathrm{M}=3.41, \mathrm{SD}=1.198)$. On the basis of the results, it can be inferred that students often felt uninterested in the courses themselves, which left a doubt as to what motivates them to apply to their current courses, be it family pressure or other possible reasons.

Table 9. Mean Scores for Self-Inflicted Stress Items

\begin{tabular}{|l|l|l|l|}
\hline No. & ITEMS & Mean & Std. Deviation \\
\hline 30. & $\begin{array}{l}\text { I feel that my studying level is not as good as that of my } \\
\text { peers. }\end{array}$ & 3.41 & 1.198 \\
\hline 31. & $\begin{array}{l}\text { I feel that I have so many courses that is beyond my } \\
\text { capability. }\end{array}$ & 3.47 & 1.259 \\
\hline 32. & $\begin{array}{l}\text { I feel that I have no interest in some courses in } \\
\text { academics. }\end{array}$ & 3.61 & 1.238 \\
\hline 33. & $\begin{array}{l}\text { I felt that my performance was not as good as I had } \\
\text { expected after I entered university, }\end{array}$ & 3.61 & 1.333 \\
\hline
\end{tabular}

Table 10 summarizes the list of the source of stress of the first part finding on academic stress. Stress from tests (3.87) shows the highest mean scores among others, followed by stress from peers (3.65), stress from results
(3.56) and self-inflicted stress (3.53). Others sources of stress resulting in an average mean score. As stated in the table 10 , the mean value of stress from lecturers is 3.12 , stress from studying in a group is 3.8 , and stress due to time management is 3.43 .

Table 10. Total Average Mean Scores

\begin{tabular}{|l|l|l|l|}
\hline No. & Sources of Stress & $\begin{array}{l}\text { Average Mean } \\
\text { Scores }\end{array}$ & Level of Stress \\
\hline 1 & Stress from Lecturers & 3.12 & Average \\
\hline
\end{tabular}




\begin{tabular}{|l|l|l|l|}
\hline 2 & Stress from Results & 3.56 & High \\
\hline 3 & Stress from Tests & 3.87 & High \\
\hline 4 & Stress from Studying in Group & 3.38 & Average \\
\hline 5 & Stress from peers & 3.65 & High \\
\hline 6 & Stress due to Time Management & 3.43 & Average \\
\hline 7 & Self-inflicted Stress & 3.53 & High \\
\hline & Total Average Mean & $\mathbf{3 . 5 1}$ & High \\
\hline
\end{tabular}

\subsection{The level of academic stress among UTM students according to year of study}

The second part of the finding is based on the second research question, which is the level of academic stress among UTM students by year of study. Figure 1 shows the comparisons of average mean scores according to the year of study.

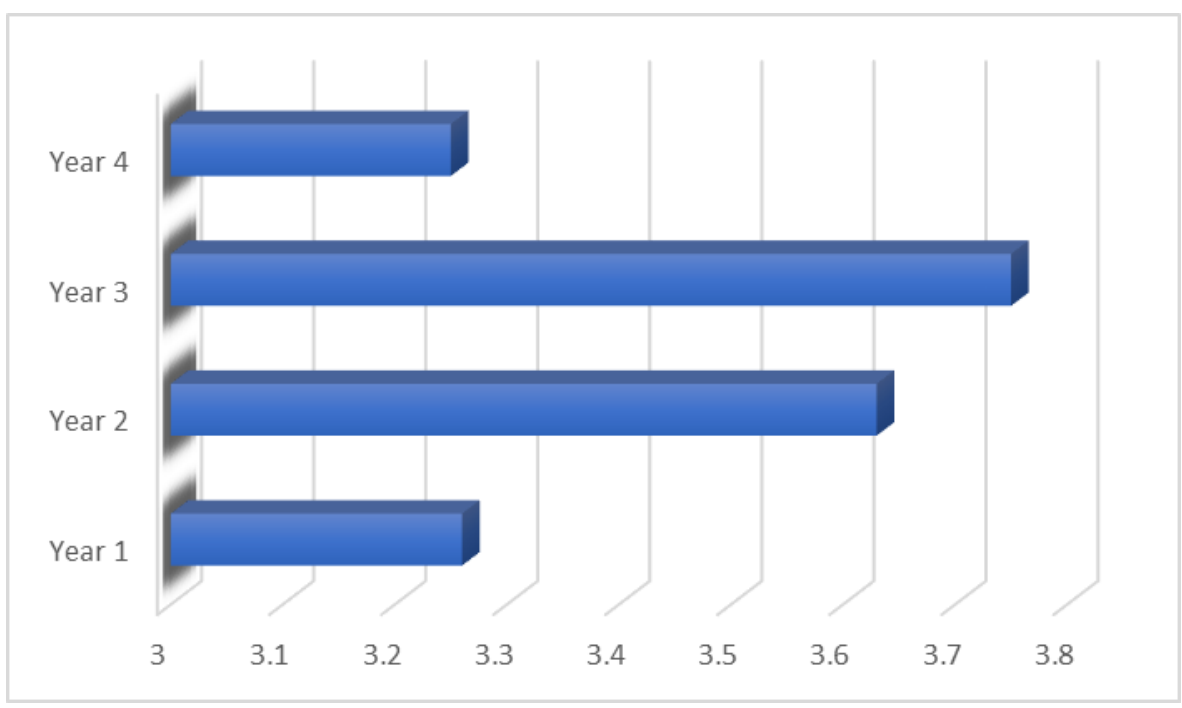

Figure 1. Comparisons of average mean scores according to year of study

According to figure 1 , there is a slightly significant difference between the mean scores between students in year 1 and 4 to year 2 and 3 . The mean scores obtained in this study shows that students in year 3 show the highest mean score, which is $M=3.75$. Followed by year 2 $(M=3.63)$, year $1(M=3.26)$ and year $4(M=3.25)$ as the lowest mean score. The findings show that students in year two and year three experience higher perceived academic stress than students in year one and year four.

\section{DISCUSSION}

Nowadays, stress is a common problem in modern life. Stress is a common thing in everyday life, and it has always been a challenge, especially to improve the mental well-being of adolescents. Stress is defined when the body has not given any specific reactions.

Psychologists describe stress as a tension experienced by an individual over a period of time that spoils the individual's ability to perform his part. Stresis able to create bodily, or mentor indications and the cause of stress can be due to the pressure as well as problem in the work environment and individual lifestyle [36]. Due to the different internal and external demands put upon their shoulders, stress has become part of the academic life of students.Adolescents are particularly vulnerable to the problems associated with academic stress as transitions occur at an individual and social level. 
Therefore, the study employed a quantitative research design using a survey towards Universiti Teknologi Malaysia students. Several studies have highlighted the causes, effects and solutions of stress problems among students in higher institutions over the years. Nevertheless, the issue remains unresolved, and students are still suffering from pressure, especially academic stress. Stress is now recognized as a lifestyle crisis affecting every person, irrespective of their stage of development. The only task students were expected to undertake was to study and to study was never perceived as stressful [37].

Given the number of possible causes of stress at university, students are especially vulnerable. Unless they have confidence in distinguishing between healthy and toxic stress, there is a risk that the stress can become a more ingrained problem. A key source of stress is a perceived lack of control over a situation [34]. Coursework deadlines and examinations are an unavoidable part of a university student's life, but students can remain in charge of these deadlines by managing time wisely and not pushing evaluation assignments and assessments until the last minute. University students also say that they get fewer hours of sleep than the eight hours a night recommended. Lack of sleep is troubling because irregular sleep cycles are correlated with low academic performance and poor quality of sleep is associated with increased stress[38].

Although the reaction to stress may be the same, the causes of stress identified by individuals differ. Such variations can be seen in the triggers, causes and effects of stressors. In an educational environment, some of the common stressors identified include unnecessary activities, poor time management and social skills, as well as peer rivalry [39]. All of this suggests that it is important to take care of oneself, to exercise daily, to develop a routine of good sleep quality and to eat healthily. To improve one's brain function, a nutritious meal, plenty of fresh fruit and vegetables, and minimal sugar and snacks will help. This routine can help to manage stress levels and help increase focus in lectures and when revising them. [40].

In conclusion, stress has both advantages and disadvantages. If students handle stress effectively, it can bring many benefits to people. Furthermore, when individuals do not manage stress well, it can lead to many problems for people. One of the problems that can occur due to stress is anxiety. Anxiety is a growing problem in modern life. Thus, students need to learn how to manage stress more efficiently. It is normal to face the stressful condition at any point in our life. Students, however, need to be aware of their power to deal with it, control it, and use it to their advantage. There is no development without stress, and one should learn how to effectively control their condition whenever it occur.

\section{CONCLUSION}

Excellence in studies is no doubt one of the most important things as a student in higher institutions. However, it is not the only criteria that will determine future success later in their careers. There are various areas that students can polish to increase their job marketability to their prospective employers instead of entirely relying on their academic achievements. In this study, it can be concluded that students in year two and three have a high perceived academic stress compare to the students in year one and four that indicates an average perceived academic stress. It is most likely due to the heavy coursework that usually comes during the second to the third year of study. Unfortunately, this research does not include the correlations with other elements, such as academic performance and lifestyle habits, that typically contribute to the level of academic stress among students. Thus, further studies must be carried out to see the correlations between the level academic stress with the academic achievements and their lifestyle to provide a means to solve the issues that arise regarding academic stress among university students.

\section{ACKNOWLEDGMENTS}

This research work is supported by College $9 \& 10$ Fellow Council, Universiti Teknologi Malaysia.

\section{REFERENCES}

[1] Wahed, W. Y. A., \& Hassan, S. K. (2017). Prevalence and associated factors of stress, anxiety and depression among medical Fayoum University students. Alexandria Journal of Medicine, 53(1), 77-84.

[2] Calaguas, G. M. (2012). Survey of college academic stressors: Development of a new measure. Journal of Human Sciences, 9(1), 441-457.

[3] Neil, R. (1994). Stress: Taming the tyrant. Brushton, NY: TEACH Services Inc.

[4] Whitman, N. A. (1985). Student Stress: Effects and Solutions. ERIC Digest 85-1.

[5] Buchanan, J. L. (2012). Prevention of depression in the college student population: a review of the literature. Archives of Psychiatric Nursing, 26(1), 21-42.

[6] Yikealo, D., Tareke, W., \& Karvinen, I. (2018). The Level of Stress among College Students: A Case in the College of Education, Eritrea Institute of Technology. Open Science Journal, 3(4). 
[7] Shaikh, B.T., Kahloon, A., Kazmi, M., Khalid, H., Nawaz, K., Khan, K.A. \& Khan, S. (2004). Students, stress and coping Strategies: A case of Pakistani Medical School. Education for Health, 17 (3), 346-353.

[8] Franken, R. (1994). Human motivation. Pacific Grove, CA: Brooks.

[9] Struthers, C.W., Perry, R.P. and Menec, V.H. (2000). An examination of the relationship among academic stress, coping, motivation, and performance in college. Research in higher education, 41(5), pp.581592.

[10] Pluut, H., Curşeu, P. L., \& Ilies, R. (2015). Social and study related stressors and resources among university entrants: Effects on well-being and academic performance. Learning and Individual Differences, 37, 262-268.

[11] Sawatzky, R.G., Ratner, P.A., Richardson, C.G., Washburn, C., Sudmant, W. and Mirwaldt, P., (2012). Stress and depression in students: the mediating role of stress management self-efficacy. Nursing research, 61(1), pp.13-21.

[12] Youssef, F.F., (2016). Medical student stress, burnout and depression in Trinidad and Tobago. Academic Psychiatry, 40(1), pp.69-75.

[13] Andersson, C., Johnsson, K.O., Berglund, M. and Öjehagen, A. (2009). Stress and hazardous alcohol use: Associations with early dropout from university. Scandinavian journal of public health, 37(7), pp.713719.

[14] Conley, C.S., Durlak, J.A. and Kirsch, A.C. (2015). A meta-analysis of universal mental health prevention programs for higher education students. Prevention Science, 16(4), pp.487-507.

[15] Yusufov, M., Nicoloro-SantaBarbara, J., Grey, N.E., Moyer, A. \& Lobel, M., (2019). Meta-analytic evaluation of stress reduction interventions for undergraduate and graduate students. International Journal of Stress Management, 26(2), p.132.

[16] Adlaf, E.M., Gliksman, L., Demers, A. and Newton-Taylor, B. (2001). The prevalence of elevated psychological distress among Canadian undergraduates:
Findings from the 1998 Canadian Campus Survey. Journal of American College Health, 50(2), pp.67-72.

[17] Dyrbye, L.N., Thomas, M.R. and Shanafelt, T.D. (2006). Systematic review of depression, anxiety, and other indicators of psychological distress among US and Canadian medical students. Academic medicine,81(4), pp.354-373.

[18] Roberts, R., Golding, J., Towell, T. and Weinreb, I. (1999). The effects of economic circumstances on British students' mental and physical health. Journal of American College Health, 48(3), pp.103-109.

[19] Bewick, B., Koutsopoulou, G., Miles, J., Slaa, E. and Barkham, M., (2010). Changes in undergraduate students' psychological well-being as they progress through university. Studies in Higher Education, 35(6), pp.633-645.

[20] Denovan, A. and Macaskill, A. (2017). Stress and subjective well-being among first year UK undergraduate students. Journal of Happiness Studies, 18(2), pp.505525 .

[21] Barker, E. T., Howard, A. L., Villemaire-Krajden, R. \& Galambos, N. L. (2018). The rise and fall of depressive symptoms and academic stress in two samples of university students. Journal of youth and adolescence, 47, 1252-1266.

[22] Pitt, A., Oprescu, F., Tapia, G. \& Gray, M. (2018). An exploratory study of students' weekly stress levels and sources of stress during the semester. Active Learning in Higher Education, 19, 61-75.

[23] Babakova, L. (2019). Development of the Academic Stressors Scale for Bulgarian University Students. Eurasian Journal of Educational Research, 19, 115- 128.

[24] Ryan, A.M., North, E.A. and Ferguson, S. (2019). Peers and Engagement. In Handbook of Student Engagement Interventions (pp. 73-85). Academic Press.

[25] Ali, M., Asim, H., Edhi, A. I., Hashmi, M. D., Khan, M. S., Naz, F., ... \& Jehan, I. (2015). Does academic assessment system type affect levels of academic stress in medical students? A cross-sectional study from Pakistan. Medical education online, 20(1), 27706. 
[26] Malathi, A., \& Damodaran, A. (1999). Stress due to exams in medical students-a role of Yoga. Indian journal of physiology and pharmacology, 43, 218-224.

[27] Zhao, X., Selman, R. L., \& Haste, H. (2015). Academic stress in Chinese schools and a proposed preventive intervention program. Cogent Education, 2(1), 1000477.

[28] Sreeramareddy, C. T., Shankar, P. R., Binu, V. S., Mukhopadhyay, C., Ray, B., \& Menezes, R. G. (2007). Psychological morbidity, sources of stress and coping strategies among undergraduate medical students of Nepal. BMC Medical education, 7(1), 26

[29] Oduaran, C. A., \& Akanni, A. A. (2019). Perceived Stress Effect and Socio-demographic Factors in Substance Use: A Study of Undergraduate Students in a South African University. Studies on Ethno-Medicine 13(2), pp. 17-21

[30] Metzger, I. W., Blevins, C., Calhoun, C. D., Ritchwood, T. D., Gilmore, A. K., Stewart, R., \& Bountress, K. E. (2017). An examination of the impact of maladaptive coping on the association between stressor type and alcohol use in college. Journal of American College Health, 65(8), 534-541.

[31] Kulis, S. S., Marsiglia, F. F., Nuño-Gutiérrez, B. L., Corona-Lozano, M. D., Mendoza-Meléndez, M. A., Kiehne, E., ... \& Han, S. (2019). Reciprocal effects of alcohol use and violence perpetration among early adolescents in Mexico: a gendered analysis. Journal of youth and adolescence, 1-13.

[32] Ramachandiran, M., \& Dhanapal, S. (2018). Academic Stress Among University Students: A Quantitative Study of Generation Y and Z's Perception. Pertanika Journal of Social Sciences \& Humanities, 26(3).

[33] Nagle, Y. K., \& Sharma, U. (2018). Academic stress and coping mechanism among students: An Indian perspective. Journal of Child and Adolescent Psychiatry, 2(1).
[34] Bedewy, D., \& Gabriel, A. (2015). Examining perceptions of academic stress and its sources among university students: The Perception of Academic Stress Scale. Health psychology open, 2(2), 2055102915596714.

[35] Lin, Y. M., \& Chen, F. S. (2009). Academic stress inventory of students at universities and colleges of technology. World Transactions on Engineering and Technology Education, 7(2), 157-162.

[36] Abdel Wahed, W. Y., \& Hassan, S. K. (2019). Prevalence and associated factors of stress, anxiety and depression among medical Fayoum University students. Alexandria Journal of Medicine, 53(1), 77-84. doi:10.1016/j.ajme.2016.01.005

[37] Galante, J., Dufour, G., Vainre, M., Wagner, A. P., Stochl, J., Benton, A., . . . Jones, P. B. (2018). A mindfulness-based intervention to increase resilience to stress in university students (the Mindful Student Study): a pragmatic randomised controlled trial. The Lancet Public Health, 3(2), e72-e81. doi:10.1016/s24682667(17)30231-1

[38]Doolin, J., Vilches, J. E., Cooper, C., Gipson, C., \& Sorensen, W. (2018). Perceived stress and worldview influence sleep quality in Bolivian and United States university students. Sleep Health, 4(6), 565-571. doi:10.1016/j.sleh.2018.08.006

[39] Ribeiro, Í. J. S., Pereira, R., Freire, I. V., de Oliveira, B. G., Casotti, C. A., \& Boery, E. N. (2018). Stress and Quality of Life Among University Students: A Systematic Literature Review. Health Professions Education, 4(2), 70-77. doi:10.1016/j.hpe.2017.03.002

[40] Slavich, G. M. (2016). Life Stress and Health: A Review of Conceptual Issues and Recent Findings. Teach Psychol, 43(4), 346-355. doi:10.1177/0098628316662768 